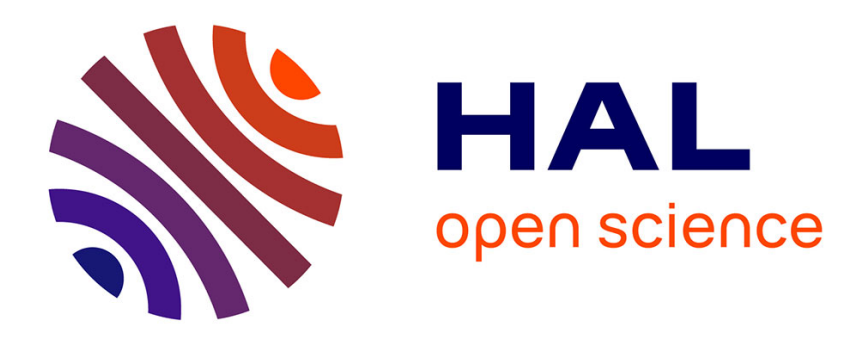

\title{
The expression of phasal polarity in Kambaata (Cushitic)

\author{
Yvonne Treis
}

\section{To cite this version:}

Yvonne Treis. The expression of phasal polarity in Kambaata (Cushitic). Raija Kramer. The Expression of Phasal Polarity in African Languages, De Gruyter Mouton, pp.311-334, 2021, 978-3-11062751-0. 10.1515/9783110646290-014 . hal-01798648v2

\section{HAL Id: hal-01798648 \\ https://hal.science/hal-01798648v2}

Submitted on 1 May 2019

HAL is a multi-disciplinary open access archive for the deposit and dissemination of scientific research documents, whether they are published or not. The documents may come from teaching and research institutions in France or abroad, or from public or private research centers.
L'archive ouverte pluridisciplinaire HAL, est destinée au dépôt et à la diffusion de documents scientifiques de niveau recherche, publiés ou non, émanant des établissements d'enseignement et de recherche français ou étrangers, des laboratoires publics ou privés. 


\title{
The expression of phasal polarity in Kambaata (Cushitic)
}

\author{
Yvonne Treis \\ CNRS-LLACAN \\ yvonne.treis@cnrs.fr
}

\section{Introduction}

Kambaata ${ }^{1}$ is a Highland East Cushitic language of Ethiopia, which does not seem to have dedicated grammatical or lexical means to express phasal polarity. This first impression, which will undergo careful scrutiny in $\S 3$ of this chapter, is gained from a cursory review of parallel texts in which the phasal polarity adverbs already, not yet, still, no longer of the English translation usually have no apparent translational equivalents in Kambaata. In (1) it is seen that English 'has not yet come' corresponds to Kambaata 'has not come', which does not convey that the hour will come later and which does not transport the speaker's judgement that this change is later than expected (or hoped for). Similarly, in (2), English 'are already white' is not reflected in the Kambaata translation, which is literally translatable as 'is grey/has become grey'. The Kambaata translation presupposes a preceding change (see the use of the inchoative-stative ideophone búll=ih- 'become grey'), but does not convey that the speaker considers the change to be earlier than expected. ${ }^{2}$

$$
\begin{aligned}
& \text { Yesúus- } u<n>k u \quad \text { "Mánch-o (...) j-éechch-u-’i } \\
& \text { Jesus-mNOM }<\mathrm{N}>\text { person.SG-fVOC time-SG-fNOM-1sPOSS } \\
& \text { iill-it-im-bá'a" y-ée-se. } \\
& \text { arrive-3f-NIPV-NEG1 say-3mPFV-3fO }
\end{aligned}
$$

'Jesus said to her, "Woman, (...) my hour (lit. time) has not yet come (lit. has

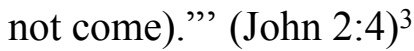

$$
\begin{aligned}
& \text { (...) Ill-i-'nne xóqq=at-téen wíx-at } \\
& \text { eye-fACC-2pPOSS lift.IDEO=do-2pPCO grain-fNOM } \\
& \text { búll }=i k-k o ́ o=g-a \quad \text { xuujj-iyyé. } \\
& \text { grey.IDEO=become-3fPFV.REL=G-mACC see-[2p]IMP }
\end{aligned}
$$

'(...) lift up your eyes and look at the fields, for they are already white for harvest (lit. lift up your eyes and see that the grain is grey/has become grey)!' (John 4:35)

Phasal polarity items express, firstly, that two situations that are temporally related phases have contrasting polarity values and to transport, secondly, the speaker's attitude towards the situation described, namely that a change is earlier ('already') or later ('not yet') than expected or that a situation persists longer ('still') or ended earlier ('any longer') than anticipated. Based on a corpus of translated texts and a corpus of spontaneous and elicited fieldwork data, this chapter investigates how

\footnotetext{
${ }^{1}$ I am grateful to Deginet Wotango Doyiso for the discussion of the data and the analyses presented in this chapter.

2 All Kambaata examples from locally published sources are provided with stress marks, segmented, glossed and translated by the present author.

${ }^{3}$ Here and for other examples from the Kambaata Bible the English translation of the New King James Version (NKJV) is given.
} 
phasal polarity is expressed in Kambaata, in view of the apparent lack of dedicated means. I describe how phasal polarity is expressed periphrastically and which adverbials adopt a phasal polarity reading in certain contexts. The necessary background for the study is provided by $\S 2$, which introduces the sociolinguistic and typological profile of the language, and $\S 3$, which summarizes how negative polarity is marked. Section 4, the core of this chapter, shows that Kambaata has several "workarounds" to express 'already' (§4.1), 'not yet' (§4.2), 'still' (§4.2) and 'no longer' (§4.3). Section 5 analyses the experiential perfect construction 'have (n)ever V-ed', which may sometimes adopt a phasal polarity reading. The discussion is concluded in $\S 6$. To the best of my knowledge, the expression of phasal polarity has so far not been investigated for any Cushitic language or any language of the Ethiopian Linguistic Area. Therefore, I am unable to say, at the present moment, whether Kambaata is a typical or untypical language in its family or area with respect to the means it employs to express phasal polarity.

\section{Sociolinguistic and typological profile}

Kambaata is spoken by more than 600,000 speakers (Central Statistical Agency 2007: 74) in the Kambaata-Xambaaro Zone in the Southern Region of Ethiopia. The immediate neighbours are speakers of other HEC languages (Hadiyya and Alaaba) and Ometo languages of the Omotic family (Wolaitta and Dawro). The most widespread second language of Kambaata speakers is the Ethiopian lingua franca Amharic. Kambaata is used as a medium of instruction in public primary schools and taught as a subject up to grade 12; in 2018, Wachamo University started a Kambaata language B.A. program on its Duuraame campus. The official Kambaata orthography is based on the Latin script (Treis 2008: 73-80, Alemu 2016) and follows the spelling conventions of the Oromo Qubee script. The Kambaata orthography is adopted in this contribution with one minor adaptation: phonemic stress is consistently marked throughout the paper by an acute accent. The following Kambaata graphemes are not in accordance with the IPA conventions: $\langle\mathrm{ph}>/ \mathrm{p} /,<\mathrm{x}>/ \mathrm{t} /,<\mathrm{q}>/ \mathrm{k} /,<\mathrm{j}>/ \mathrm{d} 3 /,<\mathrm{c}>$ $/ \mathrm{t} \mathrm{f} /,<\mathrm{ch}>/ \mathrm{t} \mathrm{f} /,<\mathrm{sh}>/ \mathrm{J} /,<\mathrm{y}>/ \mathrm{j} /$ and $<>>\mathrm{P} /$. Geminate consonants and long vowels are marked by doubling, e.g. $<$ shsh $>/ \int: /$ and $<$ ee $>/$ e:/.

Kambaata is agglutinating-fusional and strictly suffixing. Its constituent order is consistently head-final; hence all modifiers precede the noun in the NP, and all dependent clauses precede independent main clauses. The last constituent in a sentence is usually a fully finite main verb or a copula. The following open word classes are defined on morphosyntactic grounds: nouns, adjectives, verbs and ideophones.

Kambaata is a nominative-accusative language; the nominative is the subject case see jéechchu'i 'my time' in (1); the accusative marks direct objects - see illi'nne 'your (p) eyes' in (2) - and certain adverbial constituents, it also serves as the citation form of nouns and adjectives. Nouns are marked for gender (masculine vs. feminine); as in French, the assignment of grammatical gender is mostly arbitrary, with the exception of nouns referring to human beings and higher animals. Nouns distinguish nine case forms (nominative, accusative, genitive, dative, ablative, instrumental, locative, oblique, predicative), all of which are marked by a segmental suffix and a specific stress pattern. Attributive adjectives agree with their head noun in case and gender. The case system of attributive adjectives is reduced to three forms, namely nominative, accusative and oblique, with the oblique form marking agreement with non-nominative/non-accusative head nouns. 
The word class of adverbs is negligibly small. So far only a handful of morphologically invariant lexemes expressing adverbial relations could be determined, e.g. léelan 'carefully, slowly', dángo 'suddenly, unexpectedly'. In place of adverbs, Kambaata uses converbs or adjectives and nouns that are marked for adverbial cases (e.g. accusative, oblique, instrumental). Hence temporal adverbials are case-marked nouns in Kambaata; see, e.g., ga'-áata (fACC) 'tomorrow', kabár 'today (mOBL)'.

Kambaata distinguishes between fully finite main clause verbs and various types of dependent clause verbs, which are reduced in finiteness, i.e. relative verbs, converbs, purposive verbs and (infinite) verbal nouns. On affirmative main verbs, seven discontinuous subject indexes, which reflect the person, number, gender and honorificity of the subject, are distinguished. Main verbs are further marked for four aspectual categories (imperfective, perfective, perfect, progressive) and three modal categories (declarative, imperative/jussive, apprehensive). Derivational morphology (e.g. passive, causative, middle) is found between the root and the inflection (Figure 1). The use of pronominal object suffixes is partly pragmatically determined and depends on the referential prominence of the object. The last element of the verbal complex is the past tense marker $i k k e$.

\begin{tabular}{|l|l||c|c||c||}
\hline Root & (Derivation) & $\begin{array}{c}\text { I n f l e c t i o n } \\
\text { index (slot 1) }\end{array}$ & Aspect & $\begin{array}{c}\text { Subject } \\
\text { index (slot 2) }\end{array}$
\end{tabular}$\|$ (Object) $i k k e$

Figure 1. Structure of an affirmative declarative main verb

The inflectional potential of dependent clause verbs is less rich than that of main verb forms: certain person/gender and aspectual distinctions are neutralized, they cannot be marked for mood, and only some of them allow for object suffixes.

In the next section the negation mechanisms of Kambaata are summarized.

\section{Negation}

The morphology of negative (vs. affirmative) verb forms has been described in detail in earlier publications - see Treis (2012a) on negative verb forms in Kambaata and related HEC languages, Treis (2012b: 86-90) on negative converbs and Treis (2012c) on negative participles - and is here only summarized briefly. As in many languages in the world, the affirmative and negative verb forms and paradigms do not neatly match each other in a one-to-one relation but paradigmatic and constructional asymmetries (in the sense of Miestamo 2008) can be observed: Not all affirmative paradigms have dedicated negative counterparts, and negation may trigger changes in the morphological makeup of the verb form. Kambaata has five inflectional negation morphemes (Table 1). Negative morphemes are always located after the subject indexes and aspectual morphology, and before tense marking; their position relative to mood and object marking depends on the type of verb they combine with.

\begin{tabular}{|l|l|l|}
\hline$-b a($ 'a $)$ & NEG1 & $\begin{array}{l}\text { Negator of declarative main verbs, } \\
\text { existential yoo-, non-verbal predicates }\end{array}$ \\
\hline- oot & NEG2 & Negator of imperatives \\
\hline$-k a$ & NEG3 & Negator of jussives \\
\hline$-u^{\prime}$ nna & NEG4 & Negator of converbs \\
\hline$-u m b$ & NEG5 & Negator of relative verbs \\
\hline
\end{tabular}

Table 1. Inflectional negation morphemes 
The standard negator $-b a($ ' $a)$ (NEG1) is used for the negation of declarative main verbs (3), the existential verb yoo- (glossed: COP1) 'exist, be (located)' and nonverbal predicates (4).

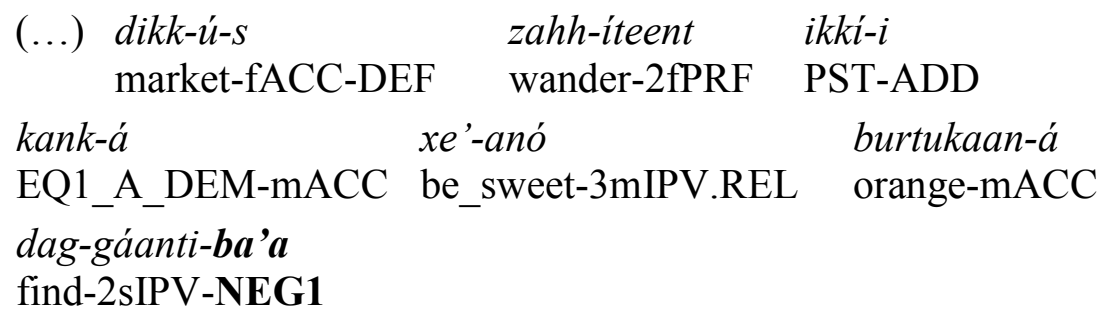

'(...) even if you trawled the market, you would not find oranges this sweet.'

(Field notes 2014)

$$
\begin{aligned}
& \text { (...) hittiin li-taa lúus-a(-ba'a) } \\
& \text { P_DEM2.fNOM 1sGEN-fCOP2 fault-fPRED(-NEG1) }
\end{aligned}
$$

'This is (not) my fault.' (Saint-Exupéry 2018: 12)

The four aspectual categories of main verbs, i.e. imperfective, perfective, perfect and progressive, are reduced to two, i.e. imperfective (3) vs. non-imperfective (1), in the negation. In the imperfective aspect, the affirmative and negative paradigm are totally symmetrical. In contrast, the non-imperfective negative verbs lack the second subject slot of their affirmative counterparts and distinguish only five (and not seven) subject indexes. The negator $-b a($ ' $a)$ precedes the object morpheme in the non-imperfective $(5)(a)^{4}$ and follows it in the imperfective (5)(b) 5
(a) xuud-een-im-bá-nne see-3hon-NIPV-NEG1-1pO
(b) xuud-éenno-nne-ba'a see-3honIPV-1sO-NEG1

(a) 'S/he (honorific) didn't see us.'

(b) 'S/he (honorific) doesn't see us.'

The morpheme -oot (NEG2) negates imperatives; it is located after the subject index but before the imperative marker and object affixes (6). ${ }^{6}$ The morpheme $-k a$ (NEG3) is the negator of jussive verbs, i.e. directive verbs of the first and third persons, where it follows the jussive morpheme $-u n$ and precedes the object suffix (7). ${ }^{7}$

$$
\begin{array}{ll}
\text { Kánne } & \text { hagág }=y \text {-it-oot }[-i] \\
\text { P_DEM1.mOBL linger.IDEO=say-2s-NEG2-[2s]IMP }
\end{array}
$$

'Don't linger here.' (Saint-Exupéry 2008: 36)
Lankaann-i
hiil-u,
land-i
kotim-u paternal_uncle-mGEN bad-mNOM leather_dress-mGEN short-mNOM Laadd-í gíd-u gambá=y-ún-ka-he!
PN-mGEN cold-mNOM encounter.IDEO=say-[3m]JUS-NEG3-2sO
(Blessing:) 'May a bad uncle, a too short leather dress and the cold of Laadda (= windy place) not catch up with you.' (Alamu \& Alamaayyo 2017: 101)

Kambaata makes a distinction between imperfective and perfective converbs, which are obligatorily marked for switch-reference (DS) ${ }^{8}$ if the subject changes between the

\footnotetext{
${ }^{4}$ See also (18) and (26).

5 See also (27).

6 See also (19).

${ }^{7}$ Subject indexes that are realized as $\varnothing$ are glossed in [ ]-brackets in the examples.

${ }^{8}$ See (35).
} 
converb and the superordinate clause. Converbs are negated with the dedicated converb negator -únna -u'nnáachch (7) -u'nnáan (NEG4), whose three allomorphs are in free variation. Object morphemes are either infixes (8) or suffixes to the converb negator. In the negative converb paradigm the distinction between the imperfective and perfective forms is neutralized; negative converbs are not sensitive to switch-reference. Negative converbs are further discussed in $\S 4.2$.

$$
\begin{aligned}
& \text { Éjj xuud-een-u'nna }<\text { 'é }>\text { echch hattig-óon } \\
& \text { before.mOBL see-3hon-NEG4 }<1 \mathrm{sO}>\text { how-fICP } \\
& \text { dag-een-o }<\text { é }>\text { ta dand-éemma-la? }
\end{aligned}
$$

'How could he (honorific) recognise me without having seen me before?'

(Saint-Exupéry 2018: 36).

The negator -umb (NEG5) negates relative verbs and all relative-based verb forms in subordinate clauses (e.g. in temporal, reason, conditional clauses). Negative relative verbs are almost perfect verb-adjective hybrids due to their combination of verbal and adjectival morphology (Treis 2012c). They agree in person, gender, number and honorificity with their subject, and in case and gender with their head noun - in (9) $u t$ $\dot{a}$ 'thorn' is both the $3 \mathrm{~m}$ subject and the masculine accusative head noun of the preceding negative relative verb. ${ }^{9}$ While affirmative relative verbs distinguish four aspectual values (imperfective, perfective, perfect, progressive), these are completely neutralized in the negation. The relative negator is found between the subject morphology (which is $\varnothing$ for $3 \mathrm{~m}$ in (9)) and the case/gender morphology.

$$
\begin{array}{lll}
\text { (...) fiit-it } & \text { hoolam-á } & \text { haww-it-án } \\
& \text { flower-fNOM much-mACC } & \text { trouble-3f-ICO }
\end{array}
$$

$\left[m e x x-u=r r-a ́-a \quad k a a^{\prime} l l-u m b-o-s s a ́ d\right]_{\text {Relative clause modifier }}$ single-mACC $=\mathrm{NMZp-mACC}-\mathrm{ADD}$ help-[3m]NEG5-mACC-3pO.REL
$u t-a ́$
kank-á
dooll-á le'-icc-it-án
thorn-mACC EQ1_A_DEM-mACC time-mACC grow-CAUS1.MID-3f-ICO
eger-too'ii
m-íihaa-ti-ndo (...)
stay-3fPFV.REL.NMZ1a.mNOM what-mDAT.VV-COP1-Q
'(...) why (do) flowers go to so much trouble, from time immemorial, to grow thorns which are of no use to them (...)?' (Saint-Exupéry 2018: 29).

The apprehensive, a paradigm of main verb forms expressing dangers and threats, and the purposive, a paradigm of dependent verb forms used in purpose and certain complement clauses, have no corresponding negative paradigms and thus need to be negated periphrastically (Treis 2010: 22, Treis 2018).

\section{Expression of phasal polarity}

In this section I first look for translational equivalents of phasal polarity items in published parallel texts that are available in French or English and Kambaata, i.e. the Little Prince by Antoine de Saint-Exupéry (2018) and the Gospel of John (Kambaata and Hadiyya Translation Project 2005). In a second step, the use of the constructions and lexical items that were obtained in this way is checked in my field notes, in elicited as well as spontaneous data, in order to determine whether these constructions

\footnotetext{
${ }^{9}$ See also (34), in which a negative relative verb is indexed for a 1 s subject and displays agreement with a feminine nominative head noun, which is not coreferential with the subject.
} 
and lexemes are dedicated phasal polarity items or whether they have another core meaning, with phasal polarity readings being restricted to certain contexts.

\subsection{Already}

In the English version ${ }^{10}$ of the Little Prince (Saint-Exupéry 1943), there are ten instances of already. However, in nine out of the ten cases, we do not find any translational equivalent in the Kambaata version; see, for instance, (10).

(10) [English version] No. This sheep is already very sickly. Make me another.

$$
\text { Ti hóol-ch-ut abb-is-s }
$$

A_DEM1.fNOM sheep-SG-fNOM become_big.CAUS1-3fPCO

moos-áan-ch-u-ta.

sickness-AG-SG-fPRED-fCOP2

Wol-ú misil-á ke'-ís-e-'e

other-mACC picture-mACC get_up-CAUS1-[2s]IMP-1sO

Lit. 'This sheep is very sick. Draw another picture for me.' (Saint-Exupéry 2018: 14)

In one case, English already is translated by wón-a- $n$ (11).

(11) [English version] "Forget what?" inquired the little prince, who already was sorry for him.

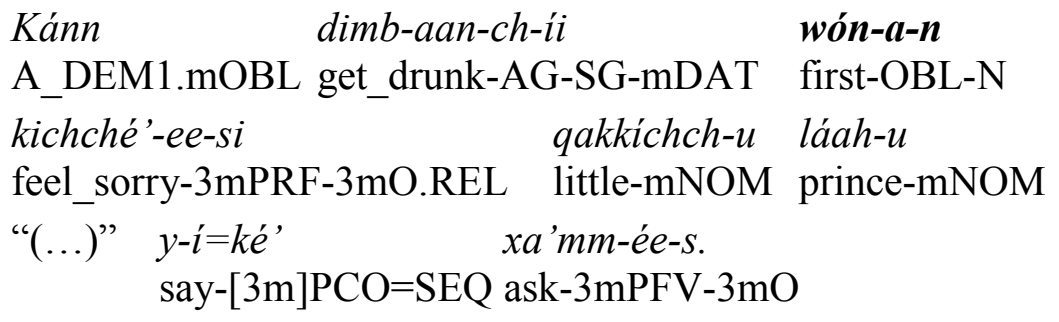

'The little prince, who was already (?) sorry for the drunkard, asked him:

“(...)”.' (Saint-Exupéry 2018: 44)

Wónan is also attested as the translational equivalent of 'already' in the translation of John 9:27 ('I told you already, and you did not listen'); elsewhere in the same text, 'already' is left untranslated. Furthermore, wóna- $n$ is found in sentence 31 of Östen Dahl's perfect questionnaire (2000), which I elicited in 2005 (12). Note that the Little Prince and the Gospel of John were translated by different Kambaata native speakers.

[The baby wakes up one hour earlier than expected and starts screaming.

Mother (in another room):] Oh no! He WAKE UP already.

Wón-a-n báqq=y-ée'u

first-OBL ${ }^{11}$-N wake_up.IDEO=say-3mPFV

'He woke up already (?).' (Field notes, elicited)

In the above examples, the translation 'already' is followed by question mark because I suspect it to be influenced by the English source or meta-language. Wón-a-n is a

\footnotetext{
${ }^{10}$ In the French original of the Petit Prince (Saint-Exupéry 1946), we find twelve instances of déjà 'already', two of which were left untranslated by Katherine Woods.

11 Usually, all lexemes with nominal, pronominal and adjectival morphology receive a gloss for case and gender. However, as the paradigms of many temporal nouns are defective, I am sometimes unable to determine their gender. The ending ' $-a$ could be the oblique case form of a masculine or feminine noun.
} 
temporal adverbial and the oblique case form of the ordinal numeral 'first', won-á, combined with the pragmatically determined emphasis marker $-n$. Wón-a- $n$ seems most appropriately translated as 'at first, firstly, before, at an earlier time'. The corpus of recorded spontaneous data shows that wón- $a$ and the emphatic form wón-a-n usually express that something happens first, in the beginning of a sequence of events (13) or that something happened at an earlier point in time (14). There is no indication that wón- $a-n$ has the conventionalized implication that something happens/happened earlier than expected or that it establishes a contrast between a reference point where the situation holds and a reference point where the situation does not hold.

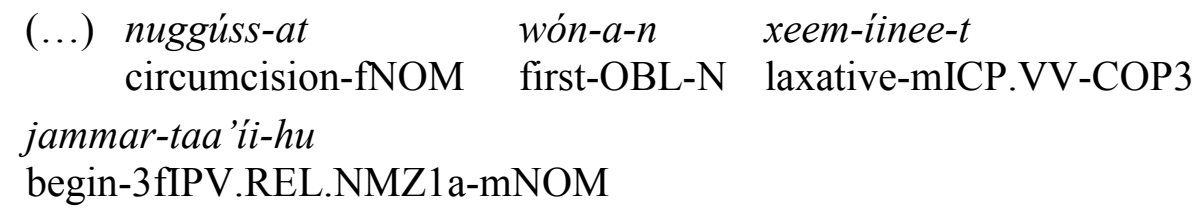

(Speaker describes the steps of a ceremony) '(...) the circumcision ceremony begins first with the (administration of the) xeemu-laxative.' (AN2016-0219_001)

$$
\begin{array}{ll}
\begin{array}{l}
\text { (...) wón-a-n atakaan-ú-s } \\
\text { first-OBL-N type_of_food-mACC-DEF }
\end{array} & \begin{array}{l}
\text { shol-een-óta } \\
\text { cook-3hon-PURP.SS }
\end{array} \\
\text { qixx-an-s-eemmá } & \text { xag-aakk-áta wor-éen (...). } \\
\text { be_ready-PASS-CAUS1-3honPFV.REL spice-PL2-fACC add-3honPCO }
\end{array}
$$

(Speaker describes the preparation of the atakaanu-dish) '(...) then one adds the different types of spices that one has prepared earlier to cook the atakaanu-dish (...).' (TH2003-06-26_atakaanu)

In Alemu's Kambaata-Amharic-English dictionary (2016: 276), éjj-i-n is translated by 'already'. Structurally similar to wón- $a-n$ 'at first', éjj-i-n is the emphatic form of the oblique case adverbial éjj[-i] 'before, formerly, previously, in the past, in the old days' (15); see also (8). As my fieldwork database shows, it is likely to be a temporal but not a dedicated phasal adverbial.
Ku
mín-u
éjj-i-n
biishsh-a-a-ndo?
A_DEM1.mNOM house-mNOM before-OBL-N red-mPRED-mCOP2-Q

(Speaker asking about the colour of a house that was recently painted) 'Was this house red before?' (Field notes 2004)

In interrogative clauses, the experiential perfect construction (\$5) may also sometimes be translated as 'have already V-ed'. The discussion in $\$ 5$ shows, however, that the construction does not qualify as a dedicated phasal polarity construction either.

\subsection{Not yet}

For the negative counterpart of 'already', i.e. 'not yet', we find various translational equivalents in the Kambaata texts. Of these, two constructions are recurrent.

In the English version of the Little Prince there are four instances of 'not yet', two of which are left untranslated, while the remaining two are translated by the temporal adverbial phrase tadáa iillán=qaxee 'until/up to now, so far' and a negated superordinate verb (16). The complex marker iillán=qaxee, which originated in an imperfective converb form of 'reach' plus a case-marked form of the noun 'extent', is the regular translation for spatial and temporal 'up to, until' and can be preceded by 
accusative-marked spatial or temporal nouns, or by an accusative-marked headless relative clauses.

(16) [English version] "Ah," I said to the little prince, "these memories of yours are very charming; but I have not yet succeeded in repairing my plane[.]"
(...) Ikkodáa
tad-áa
iill-án=qax-ee
but
now-ACC
reach-[3m] ICO=extent-mDAT
$\begin{array}{ll}a ́ n & k a \\ \text { 1sNOM } & \text { A_DEM1.mACC }\end{array}$
$b a^{\prime}-o-' e ́$
horophphill-á
makk-icc-óta
break-3mPFV-1sO.REL plane-mACC
be_made-CAUS1.MID-[1s]PURP.SS be_able-[1s]NIPV-NEG1
'(...) But I have not yet succeeded (lit. up to now I have not succeeded) in repairing the plane that broke down to my disadvantage.' (Saint-Exupéry
2018: 76)

A spontaneous example from my corpus that illustrates the use of the same temporal phrase with an affirmative superordinate clause is given in (17).

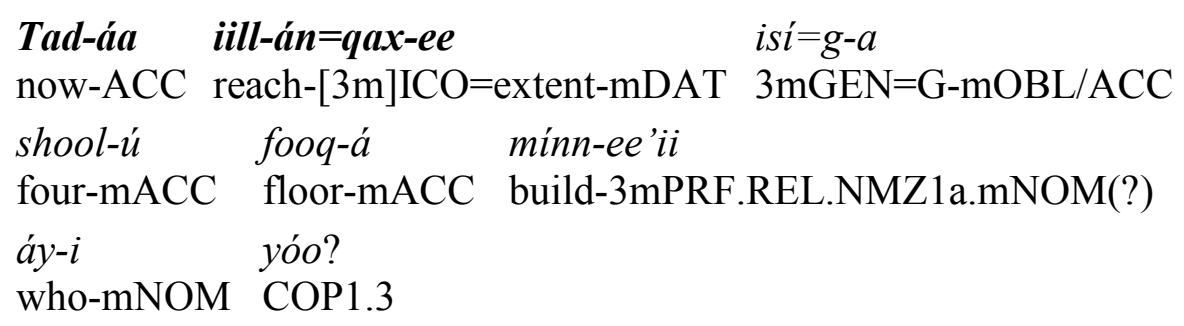

'Who has so far built (a house with) four floors like he (has done)? (Message:

Nobody has built such a house yet.)' (Field notes 2015)

In many verses where not yet is attested in the English translation of the Gospel of John, no direct Kambaata match can be determined - recall (1). However, in some examples from the same text, the translators have opted for a periphrastic verb form consisting of a negative converb ('without V-ing, before V-ing'; cf. §3) followed by the existential verb (COP1), as shown in (18)-(19). The converb and the existential are indexed for the same subject, i.e. third person (feminine) in (18) and first person singular in (19).

(18) [English version] (...) and no man laid hands on him, for his hour had not yet come.
Ikkodáa j-éechch-u-S iill-it-u'nnáachch yóo=tannée but time-SG-fNOM-3mPOSS arrive-3f-NEG4 COP1.3.REL=REAS1

'But no one seized him, because his time had not yet come (lit. his time was before/without arriving).' (John 8:20) 
(19) [English version] Do not cling to me, for I have not yet ascended to my father.

Ann- $i$ - ' $i=b-a$

ful-u'nnáan

father-mGEN-1sPOSS=PLC-mACC ascend-[1s]NEG4

yoommi=tannée af-f-óot-e-'e

COP1.1s.REL=REAS1 seize-2s-NEG2-[2s]IMP-1sO

'Do not seize me, because I have not yet ascended (lit. I am before/without

ascending) to my father.' (John 20:17)

In a draft translation of Deuteronomy (Old Testament) to which I had access, the three examples of the construction \{negative converb + existential copula\} correspond to not yet in the English version. The same construction is also attested in my own field notes collected from different speakers and at different points in time, see e.g. (20). All registered examples were - independently of each other - translated as 'not yet'.

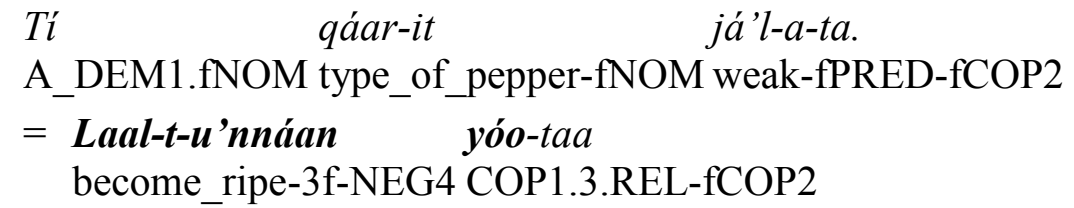

'This qaarita-pepper pod is weak. (Speaker gives a periphrasis of the first sentence:) It is not yet ripe.' (Field notes 2007)

The construction \{negative converb + existential copula\} contrasts two situations of opposing polarity, namely the actual situation in which a state does not hold and the expected situation in which the state holds. As far as I can tell from the corpus data, it often seems to transport the speaker's attitude that the anticipated change is later than expected or hoped for. It is important to note that the anticipated posterior realization of an event is already an inherent meaning component of the negative converb alone, which is not only used with the meaning 'without $\mathrm{V}$-ing' but also frequently expresses 'before $\mathrm{V}$-ing', i.e. the state of being yet to come (21).

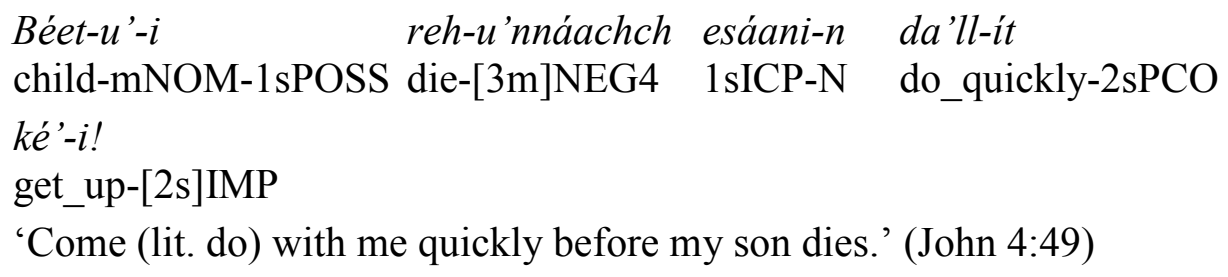

The construction \{negative converb + existential copula\} is a good (possibly the only good) candidate for a dedicated phasal polarity construction in Kambaata. A thorough semantic analysis of this construction is, however, required in the future in order to confirm this hypothesis.

Two other ways to express 'not yet' are discussed below. The negative experiential perfect construction $(\$ 5)$ sometimes has a 'not yet' reading - I show, however, that the construction does not qualify as a dedicated phasal polarity construction. Furthermore, I demonstrate in $\S 4.3$ that the temporal adverbial tees- $u$ ' $u$ ' and/even now; still; again' can acquire the reading 'not yet' in negative sentences.

\subsection{Still}

English still opposes a situation in which a state holds to an expected situation where the state does not hold. In the Kambaata translation of the Little Prince, five out of 15 instances of English still can be matched with the adverbial tees-ú-u (22). 
(22)

$\begin{array}{lll}\text { Tees-ú- } \boldsymbol{u} & \text { híkku } & \text { qakkíchch-u láah-u } \\ \text { now-mOBL-ADD } & \text { A_DEM2.mNOM } & \text { little-mNOM prince-mNOM }\end{array}$

mát-u bar-í Uull-áta fanqáll waal-áno one-mACC day-mACC Earth-fACC return.[3m]PCO come-3mIPV $y$ - $i=k e^{\prime} \quad$ horophphill-i burr $=a^{\prime}$-áan-ch-u tass-áa say-[3m]PCO=SEQ plane-mGEN fly=do-AG-SG-mNOM hope-mACC ass-áno. do-3mIPV

'The pilot (lit. plane flyer) still hopes that the little prince will return to Earth one day.' (Translation of summary of Saint-Exupéry 2018, unpublished)

$$
\begin{aligned}
& \text { (...) tees-ú-u áaz-u-s muddam-áyyoo íkke. } \\
& \text { now-mOBL-ADD interior-mNOM-3mPOSS suffer-3mPROG PST } \\
& \text { '(...) he was still worrying (lit. his interior was still suffering).' (Saint- } \\
& \text { Exupéry 2018: 88) }
\end{aligned}
$$

Tees-ú- $u$ is the additive form of tées- $u$ 'now'; thus its basic meaning is 'and now, even now' (24).

$$
\begin{aligned}
& \text { Tees-ú-u tosgoob-é goob-á barg-it=ke'éechch } \\
& \text { now-mOBL-ADD giraffe-fGEN neck-mACC add-3fPCO=SEQ } \\
& \text { wo <'>rr-itóo' (...) } \\
& \text { put_on }<\text { MID }>\text {-3fPFV }
\end{aligned}
$$

(Speaker enumerates which body parts the chameleon adopted from other animals: She ${ }^{12}$ took $x$ from a, then took $y$ from $b$, then took $z$ from $\mathrm{c} \mathrm{...)} \mathrm{'And}$ now she added the neck of a giraffe and put it on herself (because she wished to see into the distance).' (TD2016-02-11_001)

Apart from the additive (or coordinative) meaning, the adverbial tees- $u-u$ can have a persistive and a repetitive meaning, as numerous elicited and spontaneously produced examples in my corpus illustrate. Alemu (2016: 988) also mentions the three meanings of tees-ú-u in his dictionary. The persistive meaning 'still' arises in combination with stative predicates such as 'hope' and 'suffer' (22)-(23). The repetitive meaning 'again' is triggered in the context of dynamic predicates (25).

$$
\begin{aligned}
& \text { Hikkannii, ám-i, tees-ú-u hafaaffá'-i. } \\
& \text { P_DEM2.mDAT come_once-[2s]IMP now-mOBL-ADD yawn-[2s]IMP }
\end{aligned}
$$

(The king orders the little prince:) 'So, come on, yawn again!' (Saint-Exupéry 2018: 37)

Negative contexts often invite the translation 'still not, not yet'. In (26), the speaker expected the chameleon to be satisfied with all the useful and beautiful body parts that she had adopted from other animals.

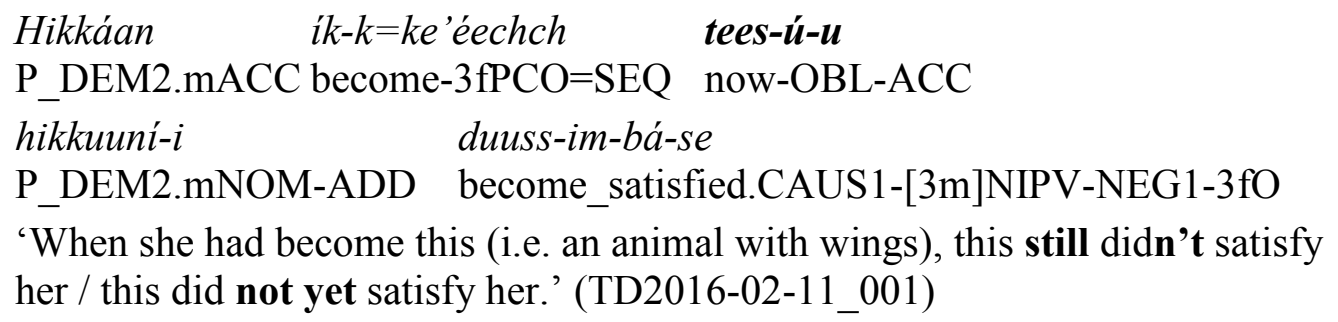

12 The chameleon is grammatically feminine in Kambaata. 
Another option to express 'still' is given in Alemu's (2016) dictionary. He translates the phrase tad-á-a iill-án=qax-ée (lit.) 'up to now' (in affirmative) as 'still' (2016: 978). Above in $\S 4.2$, we have seen the phrase being used as a translational equivalent of 'not yet' in negative sentences, but I have dismissed the hypothesis that it is a dedicated phasal polarity item.

\subsection{No longer}

In the available parallel texts no translational equivalent for 'no longer' is found. The four instances of English no longer in the Little Prince are, for instance, all left untranslated in the Kambaata version (27).

(27) [English translation] The planet now makes a complete turn every minute, and I no longer have a single second for repose.

\section{(...) esáa méxx-u fooloocc-uhú-u yoo-'e-ba'a. 1sDAT single-mNOM rest-mNOM-ADD COP1-1sO-NEG1}

Lit. '(...) I don't have a single (moment to) rest.' (Saint-Exupéry 2018: 50)

Alemu's dictionary (2016) contains no Kambaata entry for 'no longer' but gives the following translations for lankii, the adverbial (dative-marked) form of the ordinal numeral lanki 'second': 1. 'again', 2. 'never again', 3. 'any more'. Though not mentioned explicitly, translation 2 and 3 are likely to arise in combination with negative verbs - as data in my corpus confirms. The only text in which I ever used 'no longer' in the translation of Kambaata data was in a folktale from a schoolbook. The text tells the story of a heartless farmer who chases away his old horse. The farmer does no longer want to feed the horse, because it can no longer work for him. In (28), I chose to translate kanniichch zakkiin 'after this' (+ negation) as 'no longer'. Uninfluenced by Alemu (2016), which occurred after the translation of (29) was made, I interpreted lankii 'a second time, again' (+ negation) as 'no longer'.

$$
\begin{array}{lll}
\text { (...) } & \text { kanniichch zakk-íin } & \text { kées } z e '-o<h e>\text { táa } \\
& \text { P_DEM1.mABL after-mICP } & \text { 2sACC graze-[1s]PURP.SS }<2 \mathrm{sO}> \\
\text { ikko } & h e '-i s-o<h e>t a ́ a & \text { has-áam-ba'a } \\
\text { or } & \text { live-CAUS1-[1s]PURP.SS }<2 \mathrm{so}> & \text { want-1sIPV-NEG1 }
\end{array}
$$

(Farmer:) '(...) I don't want to graze and keep you any longer (lit. after this).' (Kambaatissata 1989: 6.123)

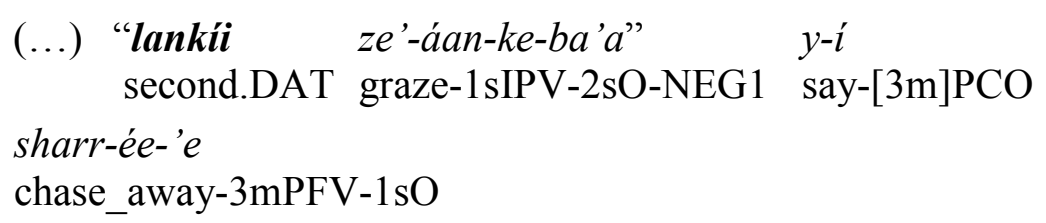

(Horse speaking about the master:) 'He said "I won't graze you any longer (lit. a second time, again)!” and chased me away.' (Kambaatissata 1989: 6.124)

\subsection{Interim conclusion}

As we have seen in the preceding sections, the phasal polarity effects of the adverbials as translational equivalents of 'already', 'not yet', 'still' and 'no longer' are contextual; none of these adverbials expresses phasal polarity by itself: wónan 'at first, firstly, before, at an earlier time' > 'already', tadáa iillán=qaxee 'until/up to now, so far' + NEG > 'not yet', teesúu 'even now' > 'still' and lankíi 'a second time' 
$+\mathrm{NEG}>$ 'no longer'. If we assume that the \{negative converb + existential $\}$ construction for the expression of 'not yet' $(\S 4.2)$ is the only potential candidate for a dedicated phasal polarity item (which would still need to be confirmed by more data and a more detailed semantic analysis), an evaluation of Kambaata phasal polarity items according to the six parameters proposed by Kramer (2018) is difficult. The Kambaata 'not yet'-construction has a rigid COVERAGE and seems to be neutral with regard to Kramer's parameter of PRAGMATICITY, as the situations that are implicitly contrasted are temporally subsequent (a present situation where a state does not hold and an expected subsequent situation where the state holds). The expected change is in the future, therefore the 'not yet'-construction qualifies as non-telic (parameter: TELICITY). As regards the parameter WORDHOOD, the Kambaata 'not yet' expression represents a case that is not covered in Kramer (2018), as it neither an independent word nor a bound morpheme but a periphrastic verb form consisting of two inflecting components that can also be used independently elsewhere. As to EXPRESSIBILITY, Kambaata has at least three "gaps" in the phasal polarity "system", because only one phasal polarity concept is expressed by a (potentially) dedicated item. It goes without saying, that one dedicated item cannot form a paradigm and that the parameter PARADIGMATICITY is not relevant for Kambaata. There is no evidence of borrowed phasal polarity items in my corpus.

\section{The experiential perfect construction}

The Kambaata experiential perfect construction expressing 'have (n)ever V-ed (once)' (30) could be mistakenly interpreted as expressing phasal polarity, because 'have (n)ever V-ed (once)' may invite the translation 'have already/not yet V-ed'. After a discussion of the morphological and syntactic properties of the experiential perfect construction and the word class status of the central '(n)ever'-morpheme, I argue that the experiential perfect should not be considered a phasal polarity construction.

$$
\begin{array}{lllll}
\text { A: Kám-i } & \multicolumn{4}{c}{\text { waayy-áno! }} \\
\text { put_away-[2s]IMP } & \text { probably_not-3mIPV } & \\
\text { Át } & \text { Duuball-i } i & \text { min-i } i & \text { már-t } & \text { kása-ndo? } \\
\text { 2sNOM } & \text { PN-mGEN } & \text { house-mACC } & \text { go-2sPCO } & \text { ever-Q }
\end{array}
$$

A: 'Come on, I doubt that! Have you ever ( already?) been (lit. gone) to Duuballa's house?'
B: Márr
kása-ba'a
gagás. Ikkodáa ... go.[1s]PCO ever-NEG1 in_fact but
B: 'I have never ( not yet?) been (lit. gone) (there), in fact. But ...' (Field notes 2014)

\subsection{Morphology and syntax of the experiential perfect construction}

The experiential perfect construction consists of a perfective converb plus a phonologically independent, non-inflecting element $k a ́ s a$, which together constitute a periphrastic verb form. The subject is marked on the converb; see már-t 2sPCO (= $3 \mathrm{fPCO})$ and márr $[1 \mathrm{~s}] \mathrm{PCO}(=[3 \mathrm{~m}] \mathrm{PCO})$ in $(30) .{ }^{13}$ A pronominal object can be attached to kása (31)-(32). The independent past tense marker ikke is placed at the end of the complex verb form (32).

\footnotetext{
${ }^{13}$ Certain subject index distinctions are neutralized in the converb paradigm (Table 2).
} 


$\begin{array}{lllll}\text { Aní- } i & \text { kées } & \text { xall-i } & \text { su'mm-íinee- } t & \text { bagáan } \\ \text { 1sNOM-ADD } & \text { 2sACC } & \text { only-mGEN } & \text { name-mICP.VV-COP3 CNTR } \\ \text { daqq-ámm } & \text { xúujj } & \text { kása-he-ba'a } \\ \text { find.MID-PASS.[1s]PCO } & \text { see.[1s]PCO } & \text { ever-2sO-NEG1 }\end{array}$

'I also know you only by name, but I have never met (or: not yet met) you.' (Kambaatissata 1989: 9.21)

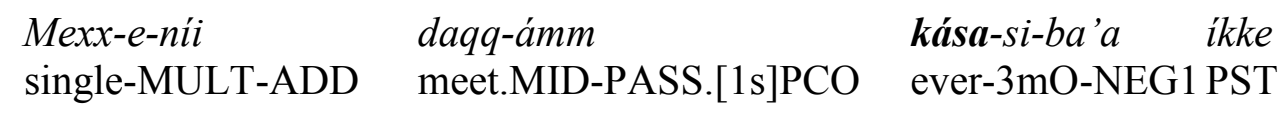

(Context: Did you know my father who died last year?) 'I had never met him once (before he died).' (Elicitation, 2004, Dahl's TMA questionnaire: \#50)

The perfective converb is a subordinate (non-final) verb form reduced in finiteness; it distinguishes five person indexes. If the perfective converb is the head of its own clause (and not part of a periphrastic verb form), the semantic relation between this clause and the superordinate clause is vague and may be interpreted as expressing anteriority, simultaneity, causality, purpose, conditionality or manner; converb and superordinate verb can also express two facets of one event. The perfective converb is one of four converb types; the imperfective, the negative and the purpose converb can, however, not form a complex verb form with kása 'ever'. Table 2 presents the perfective converb morphology; the marking consists of a segmental morpheme - the subject index - and a certain stress pattern. Only in certain $1 \mathrm{~s} / 3 \mathrm{~m}$ forms can a segmental perfective converb marker $-i$ be isolated.

\begin{tabular}{|l|l|}
\hline $1 \mathrm{~s}=3 \mathrm{~m}$ & $\begin{array}{l}\text { (after C) '(GEM/PAL)- } \varnothing ; \\
\text { (after CC) }-\varnothing-i\end{array}$ \\
\hline $2 \mathrm{~s}=3 \mathrm{f}=3 \mathrm{p}$ & '- $t$ \\
\hline $3 \mathrm{hon}$ & - éen \\
\hline $1 \mathrm{p}$ & '- $n$ \\
\hline $2 \mathrm{p}=2$ hon & -téen \\
\hline
\end{tabular}

Table 2. Perfective converb inflection

The word class status of kása is not immediately apparent. However, there is little evidence that kása is nominal or adjectival in nature, even though the final $a$ could be interpreted as a case/gender marker and its stress pattern as that of predicative nouns and adjectives (e.g. dás- $a$ slow-mPRED). The use of the standard negator $-b a($ ' $a$ ) with kása neither proves nor disproves a nominal or adjectival origin, because NEG1 is used with nominal and adjectival predicates and declarative main verbs (§3). However, unlike nouns and adjectives, kása is never combined with a copula. Many aspects speak in favor of a verbal origin of kása. The pronominal suffixes on kása are from the set of object pronouns (on verbs) and not possessive pronouns (on nouns). A distinction between these two types of dependent pronouns is generally only made in the first and second person singular; in (31) a form of the object pronoun set, -he $2 \mathrm{sO}$, is used. In two examples of the written corpus, a verbal variant of the '(n)ever'morpheme is used as the main verb in questions. In both examples, kas-inflects for $3 \mathrm{~m}$ imperfective (33). 


\author{
Kii hegeg-óon mánn-u yáa' \\ $2 \mathrm{sGEN}$ area-mLOC people-mNOM hold_a_meeting.[3m]PCO \\ kas-áno? \\ (do_)ever-3mIPV
}

'Have the people in your area ever held meetings/a meeting?' (Kambaatissata 1989: 3.41)

The verbal origin of kása is further corroborated by its behavior in relative clauses. In (34), the head noun láagat 'voice' is preceded by the adjective kohichchut 'strange' and a relative clause. The relative clause ends in the 'ever'-morpheme, which is combined with the negator $-u m b$ of relative verbs $(\S 3)$.

$$
\begin{aligned}
& \text { (...) }\left[[\text { mexx-e-níi maccoocc-í } \boldsymbol{k a s} \text {-úmb-ut }]_{\text {Relative Clause }}\right. \\
& \text { single-MULT-ADD hear-[1s]PCO (do_)ever-[1s]NEG5-fNOM } \\
& \left.[\text { kohíchch-ut }]_{\text {Adjectival Modifier }} \quad[\text { láag-at }]_{\text {Head Noun }}\right]_{\text {Subject NP }} \text { gisan-áachch } \\
& \text { strange-fNOM voice-fNOM sleep-fABL } \\
& \begin{array}{lll}
b a ́ q q=a ́ t-t & k e^{\prime}-i s-s o o-' e ́ & j \text {-áata }(\ldots) . \\
\text { wake.IDEO=do-3fPCO } & \text { get up-CAUS1-3fPFV-1sO time-fACC }
\end{array}
\end{aligned}
$$

'(...) when I was woken up from (my) sleep by a strange voice that I had

never ever heard.' (Saint-Exupéry 2018: 11)

In (34), the negative relative form of kas- is glossed as 1s. The subject index of $1 \mathrm{~s}$ and $3 \mathrm{~m}$ is both $\varnothing$ in the paradigm of negative relative verbs, but the reason clause in (35) proves that the verbal 'ever' does in fact inflect for person overtly. Reason clauses are relative clauses that are followed by an enclitic reason clause marker of nominal origin. In (35), the perfective converb (here: xúudd) and the verbal element kas- of the experiential construction are both indexed for a $3 \mathrm{f}$ subject. ${ }^{14}$

$$
\begin{aligned}
& \begin{array}{lll}
\text { [Fénd-u- } u & \text { Ludág-u- } u & \text { ám- } a \text {-ss } a \\
\text { PN-fNOM-ADD } & \text { PN-mNOM-ADD } & \text { mother-fNOM-3pPOSS }
\end{array} \\
& \text { hittig-úta ik-ki-yan xúud-d } \\
& \text { SIM2_P_DEM-fACC become-3fPCO-DS see-3fPCO } \\
& \text { kas-s-úmb-o }]_{\text {Relative Clause }}=\text { bikkii } \quad \text { hiliq-qóo'u. } \\
& \text { (do_)ever-3f-NEG5-mOBL=REAS2 shock-3fPFV }
\end{aligned}
$$

'Fendo and Ludago were shocked because they had never seen their mother like this.' (Nibaabi Jaala'e: 5)

The preceding examples have shown that the 'ever'-morpheme is verbal in nature and analyzable as an auxiliary in the synchronic state of the language. It is morphologically defective and used in the invariant form kása in declarative clauses (31). In interrogative clauses, we mostly find the invariant form, too; in two exceptional examples, a verbal form is attested (33). In relative clauses, an inflecting verbal representation of the 'ever'-morpheme is required (34)-(35). There is a strong correlation between clause type and polarity: The affirmative experiential perfect

\footnotetext{
${ }^{14}$ The $3 \mathrm{f}$ subject index is $-t$, which totally assimilates to preceding simplex consonants. Therefore, it is realized as $d$ after xuud- 'see' and $s$ after kas- '(do) ever'.
} 
construction is used in questions ('have ever V-ed (once)'), ${ }^{15}$ the negative construction in declarative clauses ('have never V-ed (once)').

Synchronically, the morpheme kas- is not used outside of the experiential perfect construction. Unlike in other Ethiopian languages, see e.g. Leslau (1995: 141) on Amharic, no etymological link can be established between the experiential perfect marker and a Kambaata or Highland East Cushitic verb 'know', and the lexical origin of kas- remains opaque.

\subsection{Semantics of the experiential perfect construction}

Could the kása-construction be analyzed as a phasal polarity construction? A study of the contexts in which the experiential constructions are used reveals that the translation 'not yet V-ed' is sometimes appropriate. In (31), which is repeated below as (31)', the speaker expresses that he has never seen the addressee; the wider context of the example makes clear that he wishes and expects this to change soon.

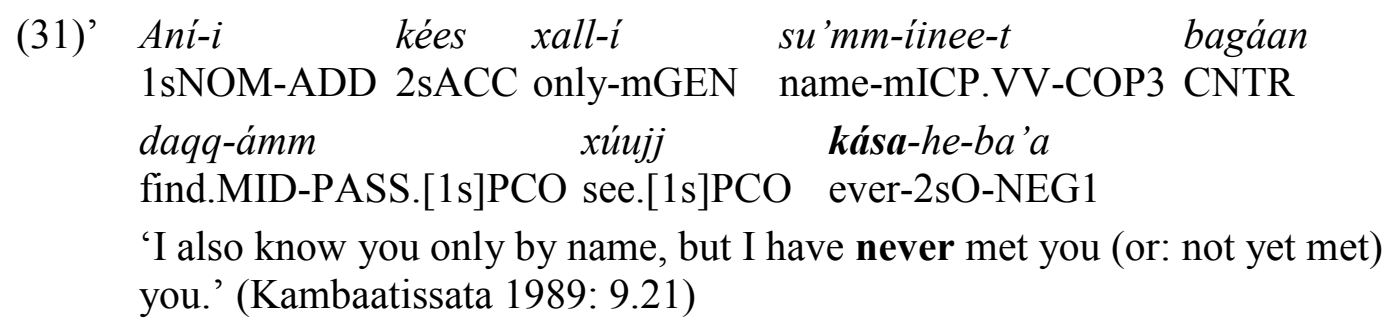

The experiential perfect construction lends itself to be translated by 'not yet', when it is clear from the context that the speaker considers an event to be realized in the near future and when this realization is considered to be late. However, native speakers did not confirm such an implication for most experiential examples in the corpus. The central semantic component of the experiential perfect construction is that an event has never happened to the subject in their lifetime. In most contexts in which the use of not yet would be natural in English, e.g. (mother speaking about the daughter) She has not yet arrived home, she must have missed the train, the experiential perfect construction is considered inappropriate, because min-í iill-ít kása-ba'a /house-mACC arrive-3fPCO ever-NEG1/ would necessarily mean that the daughter has never ever come home before. Note also that the experiential construction is often reinforced by the adverbial mexxenii 'not even a single time' (34) or the synonymous hináten.

\section{Conclusion}

In this chapter we have seen that - with the possible exception of the 'not yet'construction discussed in $\S 4.2$ - Kambaata does not have dedicated grammatical or lexical means to express phasal polarity. Kambaata does, of course, have ways to express that a situation holds already, still, not yet or no longer, but the phasal interpretation of the temporal adverbials that are then employed is exclusively contextual. Furthermore, the means that were identified in the previous sections do not form a natural set in the language, i.e. they do not represent "structured means" in the sense of Van Baar (1997: 40f), and cannot be distinguished from other temporal adverbials in the language. It is the semasiological (function-to-form) approach that I adopted in this chapter that lead me discuss formally heterogeneous means together.

\footnotetext{
15 According to discussion that I had with native speakers in February 2018, the affirmative construction is possible in declarative clauses when a speaker is not sure about their experience. See án márr kása /1sNOM go.[1s]PCO ever/ 'I have gone (there) once, I think.'
} 
The onomasiological (form-to-function) approach that is usually employed in the description of little-known languages would probably not have revealed any links between them.

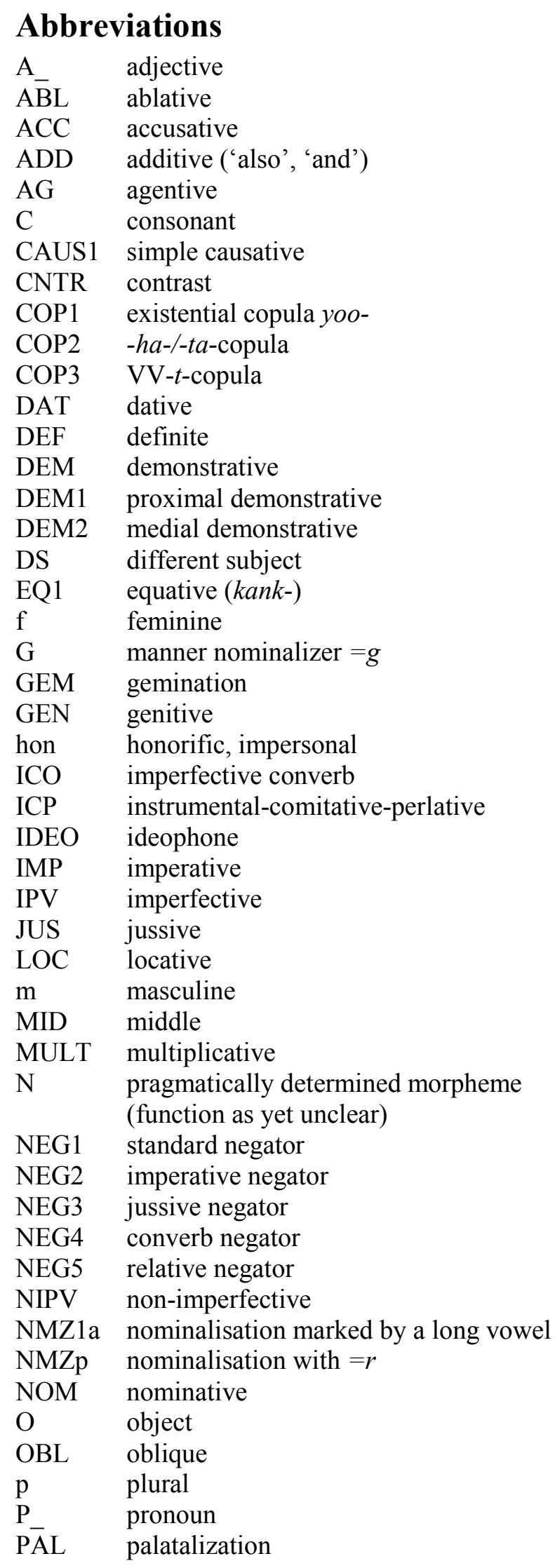




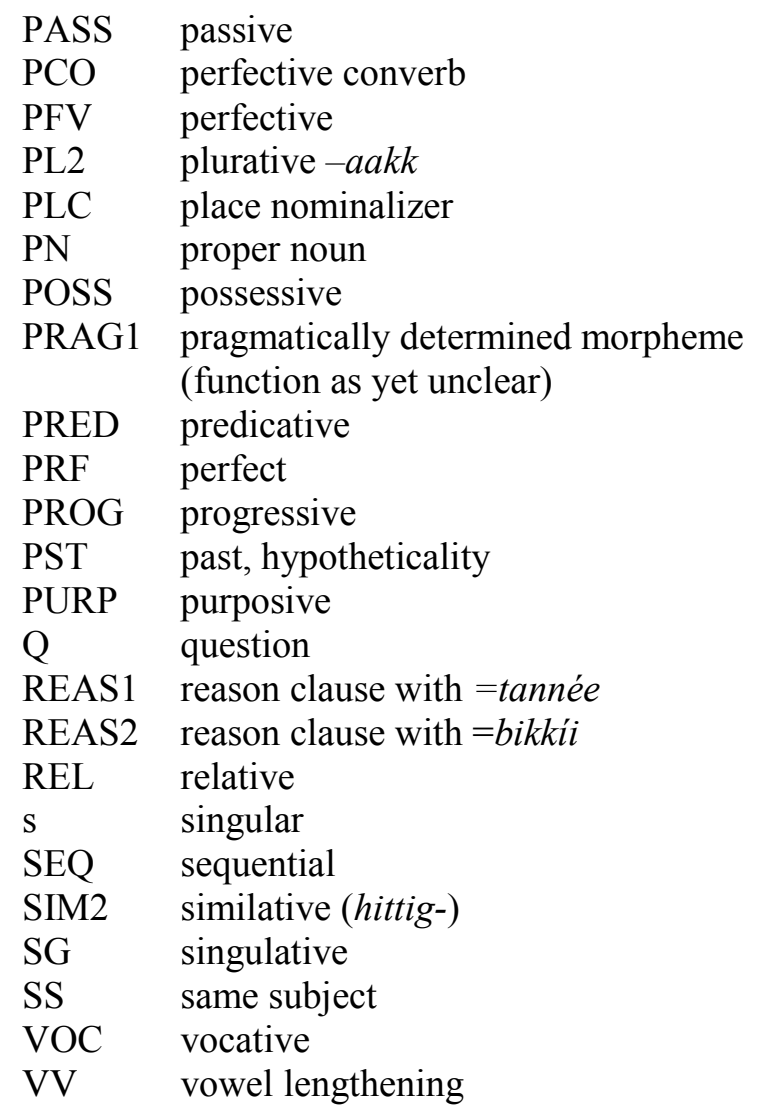

\section{References}

Alamu Banta \& Alamaayyo G/Xiyoon 2017. Hambarrichcho Yaanata. KambaatissaAmaarsa Hayyo'ooma Yannaakkata. Addis Ababa: Addis Ababa University.

Alemu Banta Atara [Alamu Banta Ataara] 2016 [2009 E.C.]. Kookaata: KambaatissaAmaarsa-Ingiliizissa Laaga Doonnuta [Kambaata-Amharic-English Dictionary]. Addis Ababa: Berhanena Selam Printing.

Central Statistical Agency 2007. Ethiopia: Population and Housing Census of 2007. http://catalog.ihsn.org/index.php/catalog/3583 (Last access: 21 August 2018).

Dahl, Östen 1985. The TMA questionnaire. In: Östen Dahl, Tense and Aspect Systems, pp. 198-206. Oxford: Blackwell.

Dahl, Östen 2000. The perfect questionnaire. In: Östen, Dahl (ed.), Tense and Aspect in the Languages of Europe, pp. 800-809. Berlin: Mouton de Gruyter.

Kambaatissata. Rosaanchi Maxaafa. [Kambaata Language. School Book.] 1989 E.C. Grade 1-8. Southern Nations, Nationalities, and Peoples Regional State: Education Bureau.

Kambaata and Hadiyya Translation Project-Hosaina 2005. Latin Version of the Gospel of John in Kambaata Language. Addis Ababa: The Bible Society of Ethiopia.

Kramer, Raija 2018. Position paper on Phasal Polarity expressions. Ms.

Leslau, Wolf 1995. A Reference Grammar of Amharic. Wiesbaden: Harrassowitz.

Miestamo, Matti 2008. [Chapter 113] Symmetric and asymmetric standard negation. In: Haspelmath, Martin, Matthew S. Dryer, David Gil and Bernhard Comrie (eds), The World Atlas of Language Structures Online. Munich: Max Planck Digital Library. http://wals.info/feature/113 (Last access: 30 October 2018).

Nibaabi Jaalae 2014. Vol. 1-5. Addis Ababa: Spotlight Publishers PLC. 
Saint-Exupéry, Antoine de 1943. The Little Prince. Translated by Katherine Woods. New York: Reynal \& Hitchcock.

Saint-Exupéry, Antoine de 1946. Le Petit Prince. Paris: Gallimard.

Saint-Exupéry, Antoine de 2018. Qakkichchu Laaha [Le Petit Prince]. Translated by Deginet Wotango Doyiso \& Yvonne Treis. Neckarsteinach: Tintenfaß.

Treis, Yvonne 2008. A Grammar of Kambaata. Part 1: Phonology, Morphology, and Non-verbal Predication. Cologne: Rüdiger Köppe.

Treis, Yvonne 2010. Purpose-encoding strategies in Kambaata. Afrika und Übersee 91: 1-38.

Treis, Yvonne 2012a. Negation in Highland East Cushitic. In: Zuckermann, Ghil'ad (ed.). Burning Issues in Afro-Asiatic Linguistics, pp. 20-61. Cambridge: Cambridge Scholars Publishing.

Treis, Yvonne 2012b. Switch-reference and Omotic-Cushitic language contact in Southwest Ethiopia. Journal of Language Contact 5: 80-116.

Treis, Yvonne 2012c. Categorial hybrids in Kambaata. Journal of African Languages and Linguistics 33, 2: 215-254.

Treis, Yvonne 2018. The apprehensive paradigm of Kambaata. Paper presented at the $51^{\text {st }}$ Annual Meeting of the SLE, 29 August - 1 September 2018, Tallinn. https://hal.archives-ouvertes.fr/hal-01866064 (Last access: 30 October 2018).

Van Baar, Theodorus M. 1997. Phasal polarity. Dordrecht: Foris. 